17. Boers F., Lindstromberg S. Cognitive Linguistic Approaches to Teaching Vocabulary and Phraseology. Berlin: Walter de Gruyter, 2008.396 p.

18. Fleischer W. Stilistik der deutschen Gegenwartssprache / W. Fleischer (u.a.). 2. Aufl. - Frankfurt am Main (etc.): Peter Lang, 1996. 341 s.

19. Dijk T.A. van. The Study of Discourse // Discourse as Social Interaction. Discourse Studies. № 2. A Multidisciplinary Introduction. L.: SAGE, 1997. P. 1-35.

20. Hickey L. Stylistics, Pragmatics and Pragmastylistics. In: Revue belge de philologie et d'histoire. Tome 71. fasc. 3, 1993. Langues et littératures modernes. Moderne taalen letterkunde. P. 573-586.

21. Johansen J.D. Literary Discourse. A Semiotic-Pragmatic Approach to Literature. Toronto \& L.: University of Toronto Press, 2002. 489 p.

22. Leech G. Explorations in Semantics and Pragmatics. Amsterdam: John Benjamin's Publishing Co., 1980. 230 p.

23. Strässler J. Idioms in English: A Pragmatic Analysis / Jürg Strässler. / Tübinger Beiträge zur Linguistik (B. 183). Gunter Narr Verlag, 1982. 160 p.

DOI https://doi.org/10.30525/978-9934-26-073-5-1-61

\title{
СТРАТЕГІЇ АНГЛОМОВНОЇ КОМУНІКАЦІЇ ТА ÏХ ЛІНГВІСТИЧНИЙ ЗМІСТ
}

\author{
Матковська М. В. \\ дочент кафедри англійської мови \\ Кам'янеиь-Подільського наџіонального університету \\ імені Івана Огієнка \\ м. Кам'янець-Подільський, Хмельницька область, Украӥна
}

Глибинні зв'язки між мовою і культурою є загальновизнаними, але як саме моделі комунікативної поведінки співвідносяться 3 системою культури, являє великий інтерес як для загальної теорії комунікації, так i для опису й аналізу комунікації в межах окремої мовної спільноти.

Наскільки складний і багатогранний сам феномен культури, настільки багатозначне i різноманітне використання цього поняття в різних контекстах різними науками. Услід за Е. Сепіром ми використовуємо термін «культура» як «загальні установки, погляди на життя і специфічні прояви цивілізації, які дозволяють конкретному народу визначити своє місце в світі» [3, с. 469]. Дана концепція найбільш близька нам, оскільки, 228 
кажучи про британську, українську або іншу культуру, ми неминуче намагаємося виділити ті специфічні риси народу, в яких виявляється його національна і культурна самобутність. Тому під національною культурою ми розуміємо не тільки і не стільки ті матеріальні і духовні цінності, нею створені, скільки їі специфічні прояви, які дозволяють чітко відрізнити іiі від інших культур. Специфіка комунікативної поведінки, національний стиль вербального спілкування обумовлені типом культури, яким визначаються нормативний етикет i соціальні норми [4, с. 325].

Наша мета - визначити стратегії англомовної комунікації та ототожнити їх лінгвістичний зміст.

Комунікативна стратегія - це сукупність мовних засобів і мовних прийомів для досягнення наміченої мети спілкування. Визначаємо групу стратегій 3 урахуванням таких чинників як мовна ситуація і мета спілкування, ступінь близькості знайомства, соціальний статус співрозмовників та ін.. Узагальнено можна представити стратегії дистанціювання, ухиляння, підтримання контакту, натяку.

Самі назви стратегій, які створюють групу - дистанційності, ухилення і натяку, відображають характерні риси англомовної комунікації. Вони високо презентують розвинені можливості вербального маневрування і лавірування, ухилення від прямолінійності та іносказання висловів. Цікава у зв'язку з цим знайдена Т.В. Ларіною у Е. Гофмана аналогія між знанням правил дорожнього руху i знанням правил ввічливості: "To study face saving is to study the traffic rules of social interaction» [1, с. 92]. Найяскравіше правила ввічливості виявляються в ситуаціях, що припускають вираження особистого відношення та наміру й дозволяють регулювати відповідальність за силу мовленнєвої дії і достовірність вислову. Якщо макростратегія маневрування орієнтована на будь-кого 3 тих, хто говорить, то макростратегія реагування адресована переважно тому, хто слухає, або, точніше - «другому, хто говорить», тому, хто, не перехоплюючи ініціативи, «заповнює паузи», пожвавлюючи бесіду окремими репліками і виконуючи свою основну функцію - підтримати головного, хто говорить, не допускаючи виникнення незручного мовчання.

Кожна 3 комунікативних стратегій має в англійській мові характерне лінгвістичне оформлення, відображаючи специфіку соціокультурного підходу до спілкування [5, p. 215-218]. Щоб описані вище особливості комунікативної поведінки не залишилися суто теоретичним знанням, далі переходимо до розгляду мовних засобів, які регулярно вживаються 
для реалізації вказаних стратегій в практиці мови, на основі системного підходу.

Стратегія дистанціювання припускає використання цілого ряду лексико-граматичних засобів, пов'язаних із категорією модальності. До них відносяться: зсув часового плану, умовний спосіб, питальні конструкції, модальні дієслова, модальні модифікатори - лексикосинтаксичні одиниці, орієнтовані на того, хто говорить або слухає. 3 їх допомогою можна додати висловам певну, як здається, віддаленість від реальності (роблячи їх тим самим ввічливішими). Вони також допомагають забезпечити зручну для співрозмовників абстрактну відстань, що дозволяє відчувати комфортність при спілкуванні [2, с. 96].

Визначаємо дві тактики дистанціювання, пов'язані із зсувом часового плану та з використанням модальних дієслів й умовного способу.

Часовий план умовного способу використовується як граматичний засіб зниження категоричності вислову, для того, щоб додати наказам вид ввічливого прохання і надати тактовної форми питанням особистого характеру, вираженню намірів, різного роду пропозиціям та ін. Британські дослідники вважають, що доречніше вживати вислови не в Present Simple, a Past aбо Future, які припускають певний зсув у минуле або майбутнє щодо моменту мовлення, що дає свободу вибору реплік у відповідь. Проілюструємо можливості реалізації цієї тактики на наступних прикладах: My dear Miss Woodruff, I'll have to ask you to leave this place ... Will you please leave your hadding place? [7, p. 123] (order/instruction); Will you not take them? [7, p. 265] - (suggestion/offer); My dear Mrs Poulteney, if you speak like this I shall have to reprimand you. We are not to dispute His understanding [7, p. 94] - (order/instruction); I wish to take a companion. I have difficulty in writing now. And Mrs Fairley reads so poorly. I shall be happy to provide a home for such a person [7, p. 137] (suggestion/offer); I should certainly wish to hear it before proceeding [7, $\mathrm{p}$. 158] - (request formula); I should like Mr. Fursey-Harris to call [7, p. 240] (request formula); Shall we go out for a meal somewhere downtown? [6, p. 63] - (suggestion/offer); How much did you intend to spend on buying the collection of books on art, records and clothes for me?

[6, p. 118] - (polite enquiry); I thought it might be nice to visit your parents on weekend [7, p. 291] - (suggestion). I wondered if I could have a bath in this house? [6, p. 279] - (request). На використанні простого майбутнього часу будуються загальноприйняті формули наказу/інструкції (will you...) і пропозиції (shall I/we...); для пом'якшення змісту наміру можливі також варіанти з дієсловами need i have to: You will need to wait downstairs [7, p. 169]. Варто звернути увагу на те, що «чистий» імператив 
нерідко $є$ просто образливим для англомовного співрозмовника, що рівноцінно безпосередньому замаху на свободу його дій.

Завдяки регулятивній функції культура в тій або іншій мірі визначає особливості поведінки людей. Різні аспекти дослідження культурної варіативності і національної своєрідності отримали достатнє висвітлення в працях сучасних зарубіжних і вітчизняних учених (А. Вежбицька, B.I. Карасик, В.А. Маслова, Е. Сепір, Р. Якобсон, Р. Brown \& S. Levinson, A. Wierzbicka тощо).

Сучасне суспільство характеризується постійним збільшенням, прискоренням, ущільненням i глобалізацією комунікацій. Однією 3 головних передумов успішної соціокультурної комунікації є лінгвістична спільність комунікантів, тобто наявність єдиної мови спілкування. Сьогодні для представників різних країн найбільш «об’днуючою» $\epsilon$ англійська мова, яка останніми роками отримала статус офіційної мови міжкультурного спілкування. Саме цим пояснюється підвищена увага до англійської мови на всіх рівнях світової освітньої системи. Отже, у мові знаходять своє віддзеркалення як менталітет, так і поведінка соціуму, який розмовляє нею. Передається і розвивається культура через спілкування, за допомогою якого здійснюється формування суспільства i забезпечення взаєморозуміння між його членами.

Таким чином, дистанційність базується на сильно розвиненому відчутті недоторканності приватної власності і необхідності захисту незалежності індивіда як неодмінної умови його розвитку. Британці і американці, орієнтовані на матеріальний розвиток, виявляють тенденцію до зосередженості і замкнутості на егоїстичних інтересах, що в проекції на міжособистісну взаємодію відображається в прагненні конкретних індивідів до розширення, наприклад, особистої території, сфери впливу. Очевидно, що множинність аналогічних експансивних прагнень змушує шукати компроміс - щоб уникнути зіткнення інтересів і зберегти свої позиції. Логічним наслідком цього є також необхідність маніпулювання (на різних рівнях, включаючи мовний). Для індивідуаліста характерне прагнення керувати своїм оточенням за допомогою впливу на нього. Загальна спрямованість такої «маніпулятивної» комунікації полягає в тому, щоб гнучко реагуючи на репліки співрозмовника, уникати прямої конфронтації. Потрібно зазначити, що ця очевидна суперечність 3 декларованим принципом невтручання являє собою приклад подвійних стандартів: зворотня, що нерідко залишається без уваги, сторона маніпулятивного підходу - не що інше як байдужість, що опирається на «егоцентричність» уваги. Дистанційність лежить в основі базових ціннісних орієнтацій британців - у відношенні до простору і часу, особи і 
влади. В процесі спілкування дистанціювання може слугувати могутнім інструментом впливу на оточуючих; це свого роду мистецтво, що дозволяє як у прямому розумінні слова, так і абстрактно регулювати ступінь близькості/віддаленості співрозмовників, створюючи при необхідності непереборні перешкоди для захисту своєї території.

\title{
Література:
}

1. Ларина Т.В. Категория вежливости в английской и русской коммуникативных культурах. Москва : РУДН, 2004. 345 с.

2. Сахно С.Л. «Свое - Чужое» в концептуальных структурах. Логический анализ языка. Культурные концепты. Москва : Наука, 1991. C. 95-101.

3. Сепир Э. Культура подлинная и мнимая. Избранные труды по языккознанию и культурологии. Москва : Прогресс, 1993, С. 465-493.

4. Якобсон Р.О. Речевая коммуникация; Язык в отношении к другим системам коммуникации. Избранные работы. Москва : Прогресс, 1985. C. 306-330.

5. Brown P., Levinson S. Politeness: Some Universals in Language Usage. Cambridge : Cambridge University Press, 1987. 345 p.

6. Fowles, J. A Maggot. UK : Random House, 1996. 464 p.

7. Fowles, J. The French Lieutenant's Woman. UK : Random House, 2004. $448 \mathrm{p}$.

DOI https://doi.org/10.30525/978-9934-26-073-5-1-62

\section{АБРЕВІАЦІЙНІ ОСОБЛИВОСТІ АНГЛІЙСЬКИХ НУМЕРОНІМІВ В МОВІ СОЦІАЛЬНИХ МЕРЕЖ}

\author{
Ніколаєва Т. М. \\ кандидат філологічних наук, \\ дочент кафедри іноземної філологіі \\ Київського національного університету культури і мистецтвв \\ м. Київ, Україна
}

У роботі здійснено аналіз особливостей англійських нумеронімів як типу абревіації в мові соціальних мереж. Резюмовано, що за останнє десятиліття соціальні мережі придбали велику популярність в житті суспільства, а разом 3 ними з'явився новий сленг користувачів: лексика, в якій переважають скорочені форми слів, абревіатури. Установлено, що 232 